\title{
Structural organization of the Corynebacterium glutamicum plasmid pCG100
}

\author{
AnNie Trautwetter and Carlos Blanco*
}

Laboratoire de Génétique et Physiologie Microbienne, CNRS UA 256, Université de Rennes I, Campus de Beaulieu, UFR-SVE, Av. du Général Leclerc, 35042 Rennes Cedex, France

(Received 18 January 1991; revised 30 May 1991; accepted 6 June 1991)

pCG100, a 3 kb cryptic plasmid of Corynebacterium glutamicum ATCC 13058, probably identical with pSR1 from C. glutamicum ATCC 19223, was characterized. The minimum region for autonomous replication was shown to be contained on a $1.9 \mathrm{~kb} \mathrm{BgIII-NcoI}$ fragment; a $380 \mathrm{bp} \mathrm{HindIII-SphI}$ fragment can replicate in the presence of the parental plasmid, which presumably provides a trans-acting replication factor. Derivatives of pCG100 are able to replicate in several Corynebacterium, Brevibacterium and Arthrobacter strains. pCG100 is compatible with pBL1, a cryptic plasmid of Brevibacterium lactofermentum. Shuttle plasmid vectors, containing the kanamycinresistance gene from Tn903 or from Streptococcus faecalis as selectable markers and the Amp $^{\mathrm{R}}$, Tet ${ }^{\mathrm{R}}$ or lacZ $\alpha$ genes for insertional inactivation, were constructed using the minimum replication fragment of pCG100.

\section{Introduction}

Corynebacteria are pleomorphic asporogenous Grampositive bacteria widely distributed in nature. Nonpathogenic coryneforms are industrially used to produce amino acids and nucleotides (Bousfield \& Callely, 1978).

Several cryptic plasmids have been found in corynebacteria (Martin, 1989). Two of them have been used to construct cloning vectors: $\mathrm{pBL1}$, a $4.4 \mathrm{~kb}$ Brevibacterium lactofermentum plasmid (Miwa et al., 1985; Santamaria et al., 1985) and pSR l, a $3 \mathrm{~kb}$ plasmid isolated from Corynebacterium glutamicum (Yoshihama et al., 1985). The nucleotide sequence of pBL1 has been published (Filpula et al., 1986); that of pSR1 was determined and its open reading frames described (Archer et al., 1989), but the nucleotide sequence remains to be published.

This report describes a $3 \mathrm{~kb}$ plasmid isolated from $C$. glutamicum ATCC 13058 which is very similar and possibly identical to pSR1 (Yoshihama et al., 1985), pHM1519 (Miwa et al., 1985) and pCG1 (Ozaki et al., 1984), isolated from C. glutamicum ATCC 19223, 13058 and 31808 , respectively.

\section{Methods}

Bacterial strains and plasmids. The coryneform strains screened for the presence of small plasmids were $C$. glutamicum ATCC 21650 , ATCC 21488, ATCC 21649, ATCC 21652, ATCC 21573 and ATCC

Abbreviation: MCS, multiple cloning site.
13058. The latter was used as the source of the plasmid pCG100 studied in this work.

B. lactofermentum ATCC 21086, which carries pBL1 (Yeh et al., 1986), was used for pCG100/pBLl incompatibility studies. Arthrobacter aureus, Arthrobacter simplex, Arthrobacter ureafaciens (Professor A. M. Gounot, Université Claude Bernard, Villeurbanne, private collection) and C. glutamicum ATCC 13287 were used to test pCG100 replication.

Escherichia coli NM522 (supE thi $\Delta($ lac-proAB) $\Delta($ hsdMS-mcrB $) 5$ $\mathrm{F}^{\prime}\left[\right.$ pro $\mathrm{AB}$, lac $^{\mathrm{Q}}, \Delta$ lac ZM15]) (Mead et al., 1985) was used as the recipient for transformation experiments and E. coli $\mathrm{K} 38$ (Russel \& Model, 1984), harbouring pGP1-2, for gene expression studies (Tabor \& Richardson, 1985).

E. coli plasmids used for cloning and vector construction were as follows: pBS8 (Spratt et al., 1986), pJRD16905 (this work), pSU19 and pSU20 (chloramphenicol resistance vectors derived from pSU2719 and obtained from F. de la Cruz: Martinez et al., 1988); pT7-5 and pT7-6 were used to identify pCG100-encoded polypeptides in E. coli (Tabor \& Richardson, 1985). pHP45 $\Omega$ Cm (Fellay et al., 1987) was used as source of the $\Omega$ cartridge containing the chloramphenicol $(\mathrm{Cm})$ resistance gene of pKT210. pJRD16905 and pl3313 (Fig. 1) were specifically constructed for this work. These plasmids and pBS8 (see above) contain kanamycin-resistance determinants which can be selected for in $E$. coli and in corynebacteria.

Growth conditions. All strains were grown on L-broth $\left(\mathrm{g}^{-1}\right.$ : Bactotryptone, 10; yeast extract, $5 ; \mathrm{NaCl}, 5 ; \mathrm{pH} \mathrm{7.3)}$ at $34^{\circ} \mathrm{C}$ for coryneform strains and $37^{\circ} \mathrm{C}$ for $E$. coli strains unless stated otherwise. For cloning experiments using pBS8, $E$. coli NM522 transformants were selected on MacConkey lactose plates (Miller, 1972). Kanamycin, ampicillin and chloramphenicol were used at $50 \mu \mathrm{g} \mathrm{ml}^{-1}$ and tetracycline at $10 \mu \mathrm{g} \mathrm{ml}^{-1}$. Only kanamycin (at $50 \mu \mathrm{g} \mathrm{ml}^{-1}$ ) was used for the selection of coryneform strains.

Manipulation of plasmid DNA. E. coli plasmid extraction was achieved by the alkaline extraction procedure described by Birnboim $\&$ Doly (1979). Plasmids from coryneform bacteria were extracted by a cleared-lysate technique. Cultures grown in $400 \mathrm{ml} \mathrm{L-broth}$ to an 


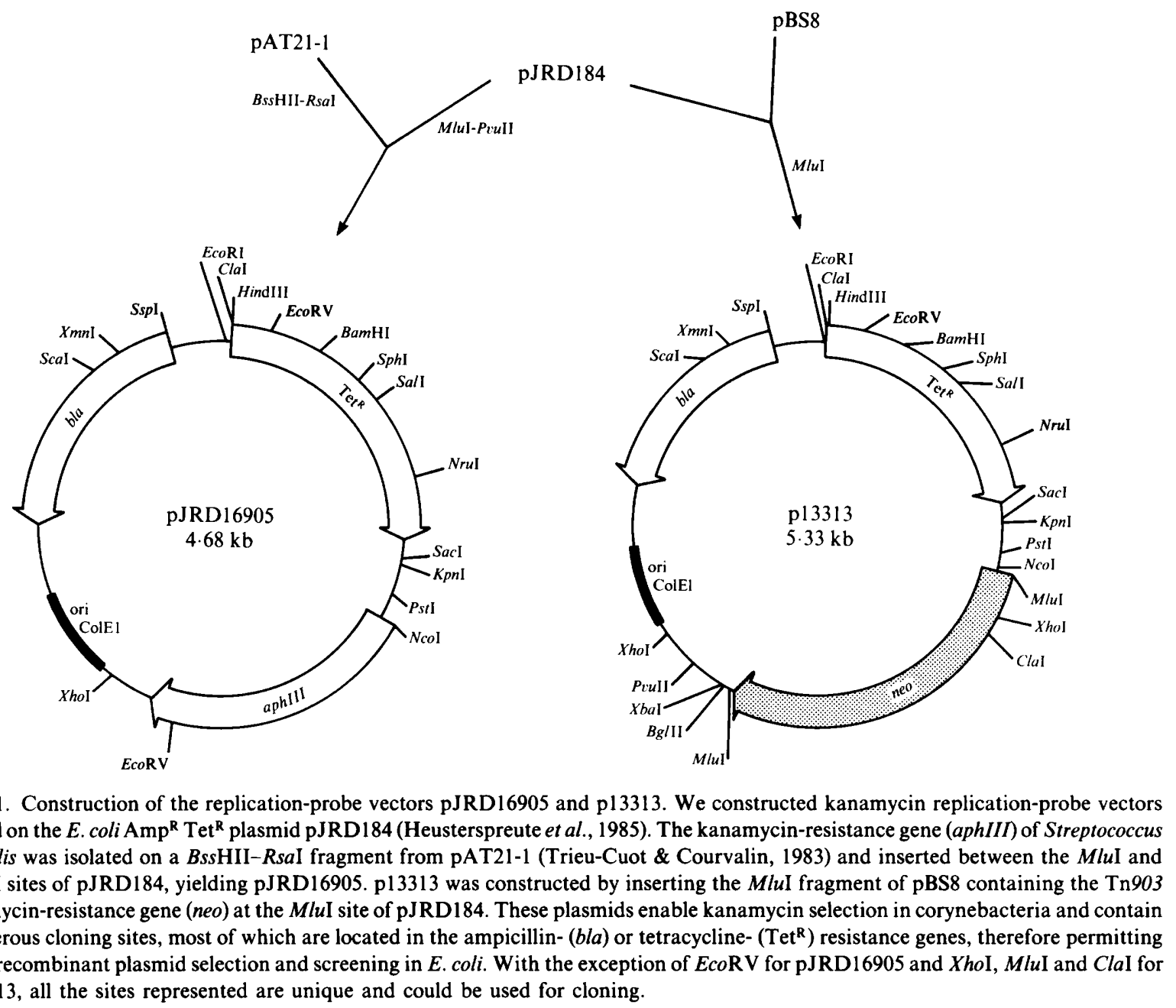

$\mathrm{OD}_{570}$ of 0.6 were treated with $0.25 \mu \mathrm{g}$ penicillin (Serva) $\mathrm{ml}^{-1}$. When the $\mathrm{OD}_{570}$ reached $1 \cdot 2$, cells were harvested, washed once with $10 \mathrm{ml}$ $10 \mathrm{~mm}$-Tris/ $\mathrm{HCl}$ buffer $\mathrm{pH} 8$ and frozen at $-80^{\circ} \mathrm{C}$ for at least $1 \mathrm{~h}$. Thawed cells were then resuspended in $4 \mathrm{ml} 10 \mathrm{~mm}$-Tris/ $\mathrm{HCl}, 10 \mathrm{~mm}$ EDTA, $10 \cdot 3 \%(\mathrm{w} / \mathrm{v})$ glucose, $\mathrm{pH} 8$, containing $10 \mathrm{mg}$ lysozyme $\mathrm{ml}^{-1}$ and incubated at $37^{\circ} \mathrm{C}$ for $60-120 \mathrm{~min}$ with shaking. After addition of $0.4 \mathrm{ml} 10 \%(\mathrm{w} / \mathrm{v})$ SDS, the suspension was thoroughly mixed, incubated for $20 \mathrm{~min}$ at $60^{\circ} \mathrm{C}$ and cooled on ice for $5 \mathrm{~min}$. $\mathrm{NaCl}$ was added to $0.5 \mathrm{M}$ final concentration and incubation on ice was continued for at least $4 \mathrm{~h}$. The plasmid-containing supernatant was collected by centrifugation at $30000 \mathrm{~g}$ for $20 \mathrm{~min}$. All plasmids were further purified by dye-buoyant centrifugation in $\mathrm{CsCl}$ gradients containing ethidium bromide (Maniatis et al., 1982).

Restriction endonuclease digestions and ligations using T4 DNA ligase were performed as recommended by the manufacturer. DNA analysis was carried out on agarose gels.

Transformation. E. coli cells were prepared for transformation with plasmid DNA by the method of Mandel \& Higa (1970).

All coryneform strains were electrotransformed by using a Gene Pulser equipped with the Pulse Controller attachment (Bio-Rad). The method used was that described by Bonnassie et al. (1990), slightly modified. Mid-exponential-phase cultures $\left(\mathrm{OD}_{570} 0.5\right)$ were treated with $0.25 \mu \mathrm{g}$ penicillin $\mathrm{ml}^{-1}$. When an $\mathrm{OD}_{570}$ of 1 was reached, cells were harvested, washed twice with $0 \cdot 1$ culture volume of $0.5 \mathrm{M}$-sucrose, resuspended in 0.01 culture volume of $0.5 \mathrm{M}$-sucrose and kept on ice until electroporation was done. For electroporation, $0.2 \mathrm{ml}$ of concentrated cells was mixed with DNA and immediately introduced into a pre-cooled $2 \mathrm{~mm}$ cuvette and pulsed with instrument settings of $25 \mu \mathrm{F}$, $2.5 \mathrm{kV}$ and $400 \Omega$. The time constant was between 5 and $7 \mathrm{~ms}$. The cell suspension was immediately diluted with $1 \mathrm{ml} \mathrm{L}$-broth and incubated at $34{ }^{\circ} \mathrm{C}$ for $90 \mathrm{~min}$ before selection of transformants on kanamycincontaining L-agar plates.

Gene expression in the bacteriophage $T 7$ promoter-RNA polymerase system. A two-plasmid system based on the properties of the T7 RNA polymerase was chosen to study pCG100-encoded polypeptides. A number of overlapping pCG 100 fragments were cloned downstream of the strong $\mathrm{T} 7 \Phi 10$ promoter, in the two possible orientations with respect to $\Phi 10$, depending on the use of pT7-5 or pT7-6 (Tabor \& Richardson, 1985). The hybrid plasmids were introduced into $E$. coli K38, which contained the compatible plasmid pGPI-2, encoding T7 RNA polymerase under the control of the inducible $\lambda \mathrm{P}_{\mathrm{L}}$ promoter and the gene encoding the heat sensitive $\lambda$ repressor $c 1857$.

To preferentially label the products of the genes cloned downstream of $\Phi 10$, a slight modification of the protocol of Tabor \& Richardson (1985) was used. Thermal induction was performed for $20 \mathrm{~min}$ at $43.5^{\circ} \mathrm{C}$, rifampicin was then added to $600 \mu \mathrm{g} \mathrm{ml}^{-1}$ and cells were 
incubated for an additional $20 \mathrm{~min}$ at the same temperature followed by $30 \mathrm{~min}$ at $30^{\circ} \mathrm{C}$. Then $10 \mu \mathrm{Ci}(370 \mathrm{kBq}) \mathrm{L}-\left[{ }^{35} \mathrm{~S}\right]$ methionine (specific activity $>1000 \mathrm{Ci} \mathrm{mmol}^{-1}$ ) was added and incubation was continued for $7 \mathrm{~min}$. Samples were submitted to SDS-PAGE $12.5 \%(\mathrm{w} / \mathrm{v})$ acrylamide with the discontinuous buffer system of Laemmli (1970). Size standards were phosphorylase $b$, bovine serum albumin, ovalbumin, carbonic anhydrase, soybean trypsin inhibitor, $\alpha$-lactalbumin, whose molecular sizes are 94, 67, 43, 30, 20.1 and 14.4 kDa respectively (Pharmacia). The gel was stained with Coomassie blue, dried and autoradiographed.

\section{Results}

\section{Isolation of pCG 100}

In order to obtain a plasmid able to replicate in $C$. glutamicum and B. lactofermentum, and also compatible with pBL1-derived vectors, we searched for plasmids in our C. glutamicum strain collection. We found $3 \mathrm{~kb}$ plasmids in strains ATCC 13058, ATCC 21560, ATCC 21488 and ATCC 21649. The $3 \mathrm{~kb}$ plasmids from all four strains gave the same DNA fragments when analysed by restriction enzyme cleavage, and the restriction map of pCG 100 from strain ATCC 13058 (Fig. 2) was similar to that previously described for pSR1 (Yoshihama et al., 1985). pCG100 and pSR1 may be identical because they were both isolated from descendants of $C$. glutamicum ATCC 13032.

\section{Identification of the minimal replication region of pCG100}

Since kanamycin resistance generally constitutes a good selection marker for coryneform bacteria, we used the $E$. coli plasmids pBS8 (Spratt et al., 1986) and pJRD16905 (Fig. 1), containing the Tn903 neomycin-resistance gene (neo) and a kanamycin-resistance gene (aphIII) of Streptococcus faecalis, respectively, to test the ability of cloned pCG100 fragments to promote replication in corynebacteria.

pBS8 and pJRD16905 were used to clone the entire pCG 100 sequence as shown in Fig. 2. pSRB1 and pSRB2 contain $B c l$-linearized pCG100 in the $B a m H I$ site of pBS8 in opposite orientations. pSRF1 contains $B g / \mathrm{II}-$ linearized pCG100 in the BamHI site of pJRD16905.

pSRB1, pSRB2 and pSRF1 were able to replicate both in $E$. coli and in the coryneform strains, $C$. glutamicum ATCC13287, B. lactofermentum ATCC 21086, ATCC 6872, A. ureafaciens, $A$. aureus and $A$. simplex. Plasmids isolated from these kanamycin-resistant transformed strains were of the expected sizes; no alteration of plasmid structure was observed after restriction enzyme cleavage. This indicated that both the $B g l I I$ and the $B c l I$ sites of pCG100 are in regions non-essential for plasmid replication.
pSRF 2, pSRF3 and pSRF4 were constructed by the insertion into pJRD16905 of the $2.5 \mathrm{~kb} \mathrm{BclI}-S c a \mathrm{I}, 2.2 \mathrm{~kb}$ $B c / \mathrm{I}-N c o l$ and $2 \mathrm{~kb} B g / \mathrm{II}-N c o I$ fragments of pCG 100 respectively (Fig. 2). These deletion derivatives of pCG 100 were able to replicate autonomously in $B$. lactofermentum ATCC 21086 and $A$. aureus lacking pCG100. The $1.9 \mathrm{~kb} B g / \mathrm{II}-N c o I$ fragment found in pSRF4 is the smallest pCG100 fragment allowing autonomous replication.

All the above self-replicating plasmids, when introduced by transformation into $C$. glutamicum ATCC 13058 , caused the loss of the resident pCG100, which lacks a resistance marker.

\section{Localization of oriV}

pSRB 3 contains the entire pCG100 sequence interrupted at the EcoRI site; pSRB4, pSRB $1 \triangle \mathrm{E}$ and $\mathrm{pSRB} 3 \triangle \mathrm{B} / \mathrm{Bg}$ contain the $2.75 \mathrm{~kb}$ HindIII, the $1.8 \mathrm{~kb} E c o \mathrm{RI}-B c / \mathrm{I}$ and the $1.6 \mathrm{~kb} E c o \mathrm{RI}-B g / \mathrm{II}$ fragments of pCG100, respectively. These four constructions and $\mathrm{pSRB} 1 / \Omega \mathrm{Cm}$ could replicate only in the presence of pCG100. Cointegrate formation was not detected when the plasmids were extracted from C. glutamicum ATCC 13058 and probed with a DNA fragment of pCG100 absent in these derivatives or when the plasmids were analysed by their restriction pattern. In all cases we observed the structure of the native pCG 100 derivative. These results indicated the existence of trans-acting pCG100 replication factors.

pSRF $1 \Delta \mathrm{H}, \mathrm{pSRF} 4 \Delta \mathrm{E}$ and pSRF5 (Fig. 2) contain the $0.2 \mathrm{~kb} H$ indIII-BglII, the $0.35 \mathrm{~kb} E c o \mathrm{RI}-N c o \mathrm{I}$ and the $2.05 \mathrm{~kb} S p h \mathrm{I}-$ EcoRI segments of pCG100 respectively. They were unable to replicate even when pCG100 was provided in trans. It therefore seems likely that oriV is located on a $0.38 \mathrm{~kb}$ fragment between $H_{\text {ind }} \mathrm{III}_{\mathrm{b}}$ and Sphl. It does not overlap these sites since plasmids containing pCG 100 deleted of its small HindIII fragment (pSRB4, Fig. 2), or with an insertion in the SphI site (pSRB1/ $\Omega$ Cm, Fig. 2) could still replicate with the help of $\mathrm{pCG} 100$.

\section{Compatibility with $p B L 1$}

The six self-replicating kanamycin-resistant pCG100 derivatives shown in Fig. 2 were maintained in $B$. lactofermentum ATCC 21086 together with $\mathrm{pBL1}$, at about equal copy number. This suggests that pCG100 and $\mathrm{pBL} 1$ are compatible replicons.

\section{Copy number}

The copy number of pCG 100 was estimated by comparing the amount of plasmid DNA in the covalently closed circular form with the amount of chromosomal DNA in 


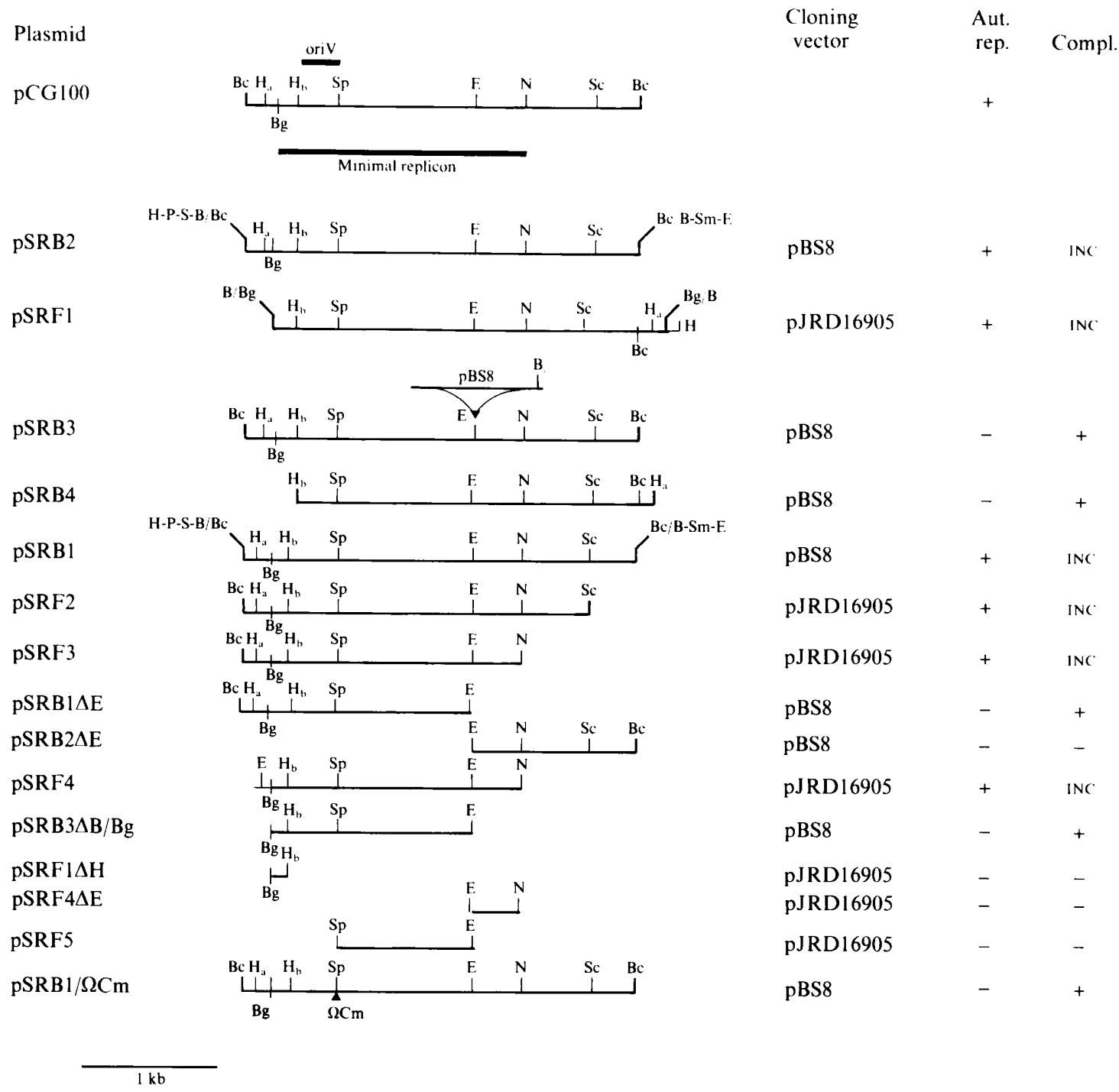

Fig. 2. Derivatives of pCG100 and their properties. pCG100 (top of Figure) was linearized at the $B c / 1$ site and inserted in both orientations into the BamHI site of pBS8 to give pSRB1 and pSRB2 respectively. pSRB3 and pSRB4 were obtained after introduction of EcoRI- or HindIII-linearized pCG100, respectively, into the corresponding sites of pBS8. Insertion of BglII-cleaved pCG 100 into the $B a m \mathrm{HI}$ site of pJRD16905 gave pSRF1. pSRF2, pSRF3 and pSRF4 were obtained by the introduction of the $B c l \mathrm{I}-\mathrm{ScaI}(2.6 \mathrm{~kb}), B c l \mathrm{l}-$ $N c o I(2.1 \mathrm{~kb})$ or $B g l \mathrm{II}-\mathrm{Ncol}(1.9 \mathrm{~kb})$ fragment, respectively, between $B a m \mathrm{HI}$ and the appropriate second sites of pJRDI6905. pSRF5 was obtained by inserting the $E c o R I-S p h I$ fragment $(0.95 \mathrm{~kb})$ between the corresponding sites of $\mathrm{pJRD} 16905$. $\mathrm{pSRB} 1 / \Omega \mathrm{Cm}$ resulted from the insertion of the $\Omega$ cartridge, containing a chloramphenicol-resistance gene, into the $S p h$ site of pSRB1.pSRB1 $\triangle E, p S R B 2 \Delta E$, pSRB $3 \Delta \mathrm{B} / \mathrm{Bg}, \mathrm{pSRF} 1 \Delta \mathrm{H}$ and pSRF $4 \Delta \mathrm{E}$ were derived by deletion of the indicated fragments from the named plasmids. All plasmids were first isolated from $E$. coli NM522 and then transformed by electroporation into corynebacteria. Only the cloned pCG100 fragments are shown. The position of relevant vector sites is indicated without scale considerations. The positions of the minimal replicon and replication origin (oriV) are shown on the pCG100 map at the top of the Figure. pSRB3 is represented linearized at its $B c / I$ site; the position and orientation of pBS8 is shown above the pSRB3 line. E. coli cloning vectors are specified in the first column to the right. The column 'Aut. rep.' indicates whether the plasmids can replicate autonomously in $B$. lactofermentum and $A$. aureus. The rightmost column indicates the ability of fragments to sustain replication in $C$. glutamicum ATCC 13058 containing pCG100: + indicates that both replicons coexist; INC indicates incompatibility, i.e. resident pCG100 is lost. B, BamHI; Bc, BclI; Bg, BglII; E, EcoRI; H, HindIII $\left(\mathrm{H}_{\mathrm{a}}\right.$ and $\mathrm{H}_{\mathrm{b}}$ denote the two HindIII sites of pCG100); N, NcoI; P, PstI; S, SalI; Sc, ScaI;Sm, SmaI;Sp, SphI.

total DNA preparations obtained according to Chater $e t$ al. (1982). Assuming that the size of chromosomal DNA of corynebacteria is around $3000 \mathrm{~kb}$ (Crombach, 1978), the copy number of pCG100 is about 30 in C. glutamicum
ATCC 13058 and in B. lactofermentum ATCC 21086. In the latter strain we found that pCG100 derivatives had the same copy number as pBL1. This result agrees with the estimation of Santamaria et al. (1984). 
(a)

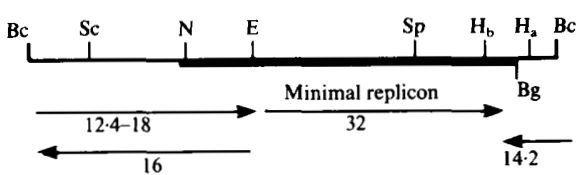

\begin{tabular}{|c|c|}
\hline Plasmid & $\begin{array}{l}\text { Lane } \\
\text { in }(b)\end{array}$ \\
\hline p21917 & A \\
\hline p21917 $\Delta E$ & B \\
\hline $\mathrm{p} 21917 \Delta \mathrm{H}$ & $\mathrm{C}$ \\
\hline p21964 & \\
\hline p21964 & $\mathrm{D}$ \\
\hline p21912 & $\mathrm{E}$ \\
\hline $\mathrm{p} 21912 \Delta \mathrm{E}$ & $\mathrm{F}$ \\
\hline $\mathrm{p} 21912 \Delta \mathrm{H}$ & G \\
\hline p21958 & \\
\hline p21958AE & $\mathrm{H}$ \\
\hline $21958 \Delta H$ & I \\
\hline
\end{tabular}
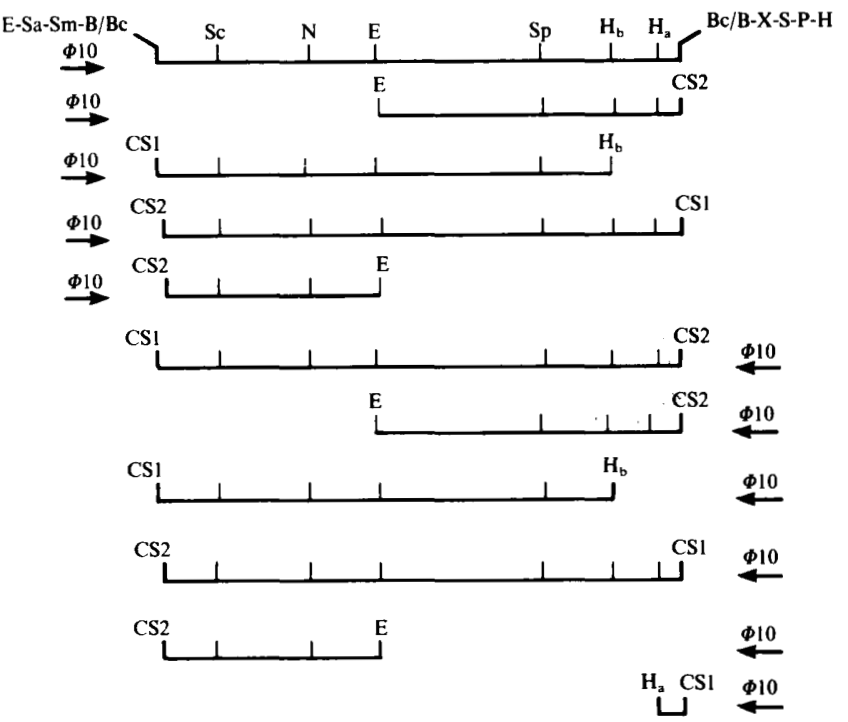

Encoded polypeptides $(\mathrm{kDa})$

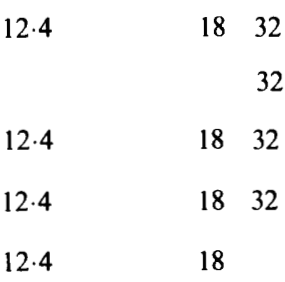

$14 \cdot 216$

$14 \cdot 2$

16

$14 \cdot 216$

16

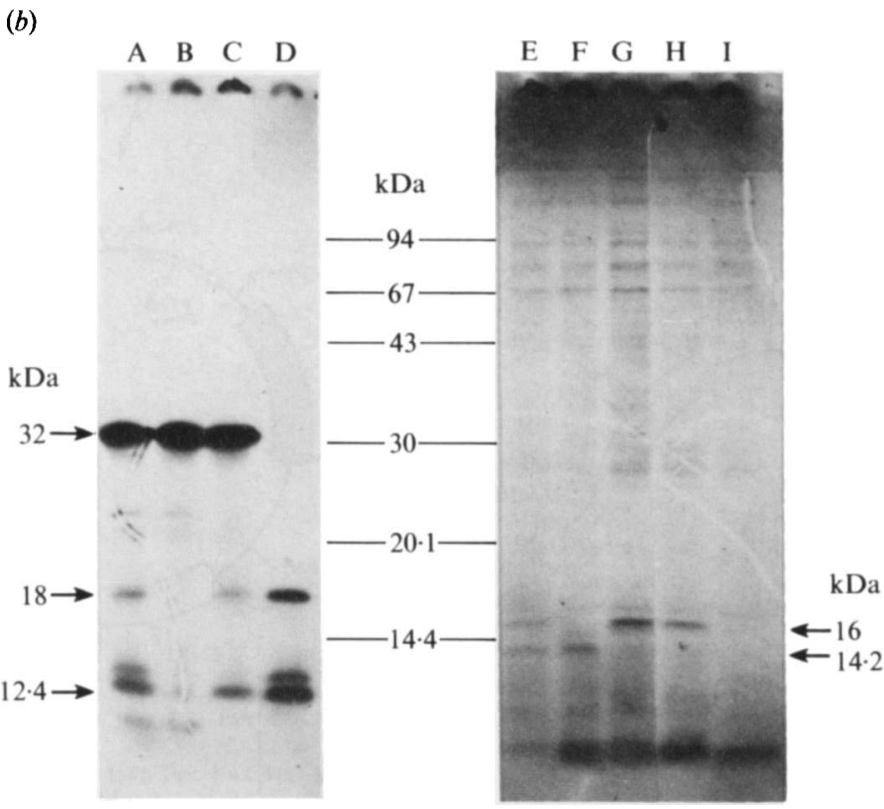

Fig. 3. Synthesis of pCG100 polypeptides in the T7 expression system of Tabor \& Richardson (1985). (a) Plasmid constructs. pCG100 was linearized with $B c /$ and ligated to $B a m H I$-linearized pT7-5 to give p21917 and p21958, which differ in the orientation of pCG 100 with respect to the $\Phi 10$ promoter; p21912 and p21964 were constructed with BamHI-linearized pT7-6. All plasmids were introduced by transformation into $E$. coli $\mathrm{K} 38$ for analysis as described in Methods. The sizes of the polypeptides expressed from each plasmid are indicated on the right (see also $b$ ). The figure shows only the pCG 100 fragments cloned into the pT7 plasmids. The arrow indicates the direction of transcription from the $\Phi 10$ promoter. CS1 and CS2 cloning sites are detailed on the left and on the right of p21917 respectively. Sa, SacI : X, XbaI; other restriction endonucleases as in Fig. 2. (b) Autoradiograph of SDS-PAGE gels showing ${ }^{35}$ S]methionine-labelled polypeptides encoded by the cloned pCG100 sequences. Lanes: A, p21917; B, p21917 E ; C, p21917

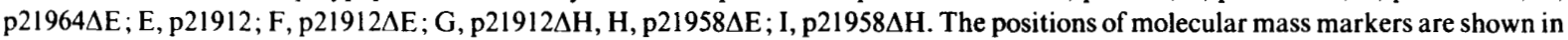
the centre. On the left and right sides are indicated the molecular masses of the pCG100-encoded polypeptides which depend on the direction of transcription analysed. Lanes A-D and E-I were exposed for $16 \mathrm{~h}$ and $2 \mathrm{~d}$ respectively. The locations of the pCG100 sequences encoding the polypeptides, and the minimal replicon are shown reported at the top of $(a)$. 
(a)

(b)

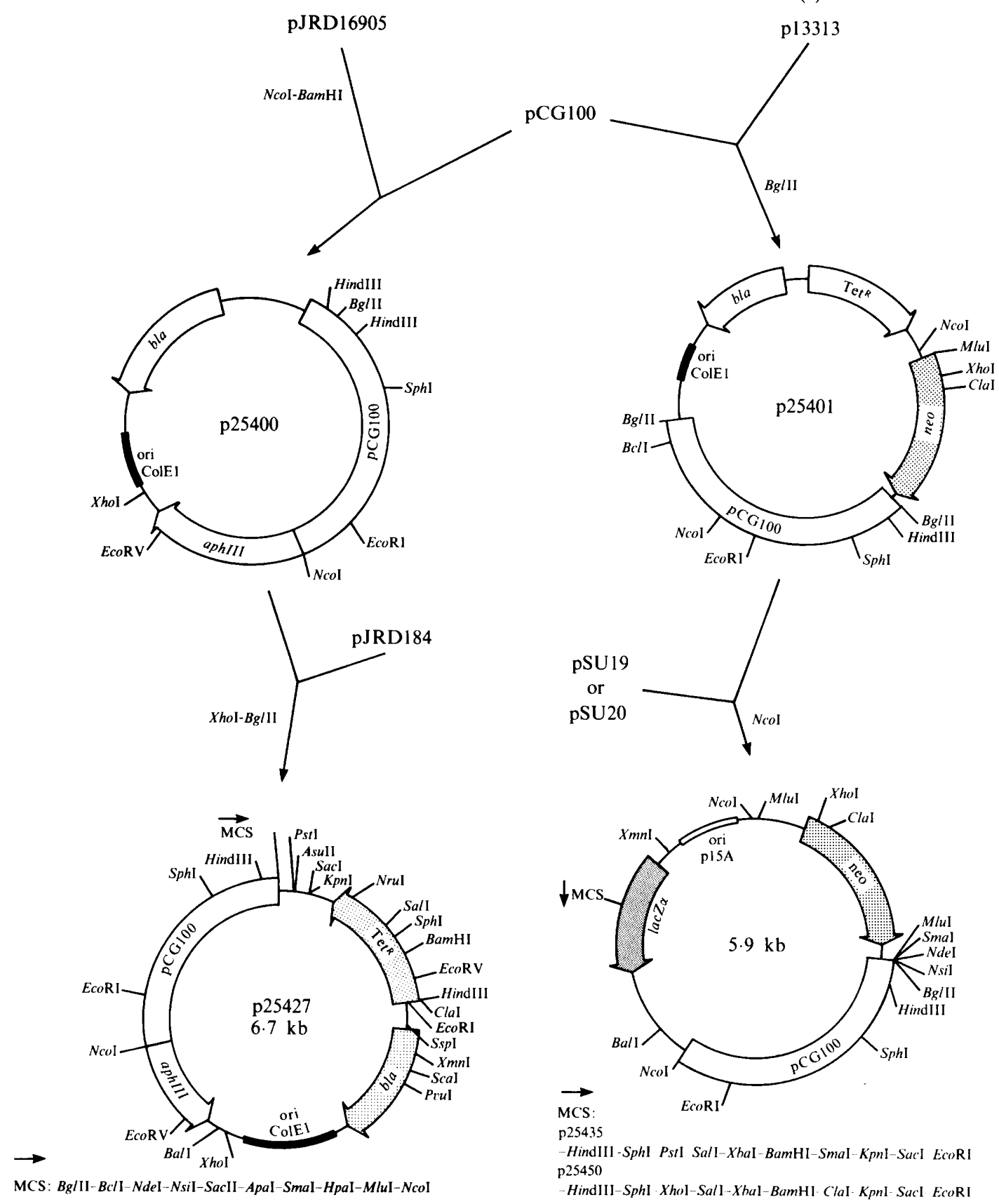

Fig. 4. Construction of E. coli/Corynebacterium shuttle vectors based on the pCG100 minimal replication region. (a) pCG100 digested with $\mathrm{NcoI}$ and $\mathrm{Bc} / \mathrm{I}$ was ligated to pJRD16905 cleaved with $\mathrm{BamHI}$ and $\mathrm{NcoI}$. The ligation mixture was used to transform $A$. aureus, a strain devoid of resident pCG 100 and suitable for pCG 100 replication. The resulting plasmid, p25400, was digested with $B g / I I$ and $X h o I$ and the DNA fragment containing both the kanamycin-resistance gene (aphIII) and the pCG100 replication region was ligated to pJRD184 cleaved with the same enzymes. The resulting plasmid, p25427, conferred an $\mathrm{Amp}^{\mathrm{R}} \mathrm{Tet}^{\mathrm{R}} \mathrm{Kan}^{\mathrm{R}}$ phenotype upon $E$. coli NM522. (b) Bg/II-cleaved pCG100 was introduced into the unique Bg/II site of p13313, to give p25401, which was selected in $A$. aureus. (The other orientation of pCG 100 in p13313 was also obtained.) The NcoI fragment bearing the neomycin resistance gene (neo) and the pCG100 replication functions was ligated to pSU19 or pSU20 linearized at their unique NcoI sites to give p25435 and p25450, respectively. The orientations of the MCS are indicated by an arrow on the plasmid maps and on the polylinkers. 


\section{Identification of pCG100-encoded polypeptides}

The entire pCG 100 sequence linearized with $B c /$ was introduced into p 7 7-5 and pT7-6 in the same orientation with respect to $\Phi 10$ promoter activity, yielding p21917 and $\mathrm{p} 21964$, respectively (Fig. $3 a$ ). These two plasmids expressed three polypeptides, of $12 \cdot 4,18$ and $32 \mathrm{kDa}$, the latter being the best labelled (Fig. $3 b$, data not shown for p21964). These polypeptides were encoded by genes transcribed from EcoRI towards HindIII. The other orientation of the pCG100 sequence with respect to the $\Phi 10$ promoter was found in $\mathrm{p} 21912$ and $\mathrm{p} 21958$, in which $B c /$-linearised pCG 100 was cloned in pT7-6 and pT7-5 respectively. These two plasmids gave rise to the synthesis of two polypeptides of 14.2 and $16 \mathrm{kDa}$ (Fig. $3 b$, data not shown for $\mathrm{p} 21958$ ).

To localize more precisely the sequences necessary for the synthesis of these polypeptides, deletion derivatives of the above four plasmids were analysed (Fig. 3). p21917 $\mathrm{H}$ still expressed the three polypeptides, whereas p21917 $\mathrm{E}$ expressed only the $32 \mathrm{kDa}$ polypeptide and $\mathrm{p} 21964 \Delta \mathrm{E}$ expressed those of 12.4 and $18 \mathrm{kDa}$. Hence, we conclude that the major polypeptide of $32 \mathrm{kDa}$ is expressed from the sequence between the EcoRI and HindIII ${ }_{\mathrm{b}}$ sites of pCG100 and that the other two polypeptides are transcribed on the same DNA strand from a sequence located between $B c l$ and $E c o$ RI.

Considering the other direction of transcription, p21912 $\Delta \mathrm{E}$ expressed only the $14.2 \mathrm{kDa}$ polypeptide, whereas p21912 $\Delta \mathrm{H}$ expressed only the $16 \mathrm{kDa}$ polypeptide. Since these two p21912 derivatives overlap on the EcoRI-HindIII ${ }_{\mathrm{b}}$ sequence, it was obvious that the $14 \cdot 2 \mathrm{kDa}$ polypeptide was encoded between the $B c / \mathrm{I}$ and $H_{\text {ind }} \mathrm{III}_{\mathrm{b}}$ sites, whereas the $16 \mathrm{kDa}$ polypeptide was encoded between $E c o$ RI and $B c I I$, as confirmed by p21958 $\triangle \mathrm{E}$ analysis (Fig. 3).

The localization of the pCG100 sequences encoding the polypeptides is summarized at the top of Fig. 3 .

\section{Shuttle vectors derived from $p C G 100$}

Three shuttle vectors based on the $B g I I I-N c o I$ fragment containing the minimum pCG100 replication region were constructed (Fig. 4). p25427 (6.7 kb) contains the entire $\mathrm{Tet}^{\mathrm{R}}$ and $\mathrm{Amp}^{\mathrm{R}}($ bla $)$ genes, the ColE1 origin of replication of pJRD184 and the aphIII gene of Streptococcus faecalis. p25435 and p25450 (each $5.9 \mathrm{~kb}$ ), derived from pSU19 and pSU20, respectively, contain the P15A replication origin, the $\operatorname{Tn} 903$ neomycin resistance gene and the lac $Z \alpha$ reporter gene of pSU19 or pSU20 respectively. These three vectors contain numerous unique cloning sites, most of them enabling resistance gene inactivation for recombinant plasmid selection in p25427 (NruI, SalI, BamHI, ClaI, XmnI, ScaI and PvuI in the Amp ${ }^{\mathrm{R}}$ or $\mathrm{Tet}^{\mathrm{R}}$ genes and unique $B g / \mathrm{I}, B c / \mathrm{I}, \mathrm{NdeI}$, NsiI, ApaI, SmaI, HpaI, MluI and SacII sites in the MCS), or direct selection of insert-containing plasmids on MacConkey lactose kanamycin plates for p25435 and p25450 (both contain unique SalI, XbaI, BamHI, KpnI and SacI sites in their MCS, and p25435 additionally contains PstI; NdeI, NsiI and Bg/II are unique sites that could also be used for cloning).

\section{Discussion}

The cryptic $3 \mathrm{~kb}$ multicopy plasmid pCG 100 found in $C$. glutamicum ATCC 13058 has a restriction map similar to that described for pSR1 (Archer et al., 1989), but the location on the pCG100 map of the region necessary for autonomous replication and of the sequences encoding polypeptides (see below) seem different from pSRI described by Archer et al. (1989).

To identify pCG100-encoded proteins we used the $E$. coli expression system described by Tabor $\&$ Richardson (1985). In this system, cloned genes are expressed from the $\Phi 10$ promoter while transcription from other promoters is inhibited by rifampicin. This method overcomes problems of heterologous promoter expression in E. coli. Various Corynebacterium genes have been cloned and expressed in E. coli (Martin, 1989); in some cases the original promoter was not effective in $E$. coli. The translation signals of known Corynebacterium genes are similar to those of $E$. coli, whereas their codon usage is slightly different (Martin, 1989). These differences do not seem to be very important since most of the aminoacid-producing genes cloned from corynebacteria were identified by complementation of $E$. coli mutants (Martin, 1989).

We have identified five polypeptides encoded by pCG100. Their molecular sizes are 12.4, 18, 32, 14.2 and $16 \mathrm{kDa}$; the first three were expressed on one of the DNA strands, the latter two on the other strand. The $32 \mathrm{kDa}$ polypeptide gave rise to the strongest bands in the T7 expression system.

Deletion experiments enabled us to localize the $32 \mathrm{kDa}$ polypeptide-coding sequence between the EcoRI and HindIII $\mathrm{b}_{\mathrm{b}}$ sites (Fig. 3). The polypeptides of 12.4 and $18 \mathrm{kDa}$, which are dispensable for pCG100 replication and expressed on the same DNA strand, are located between the $B c l I$ and $E c o$ RI sites. Considering the other direction of transcription, only two very weakly labelled polypeptides of 14.2 and $16 \mathrm{kDa}$ were expressed. The $16 \mathrm{kDa}$ protein originates from between the $E c o \mathrm{RI}$ and $B c l \mathrm{I}$ sites and the $14.2 \mathrm{kDa}$ protein from between $B c l \mathrm{I}$ and $H_{\text {ind III }}$ (Fig. 3).

The role of these polypeptides is not known. However, since the $14.2 \mathrm{kDa}$ protein is absent and the 18,16 and 
$12.4 \mathrm{kDa}$ ones are truncated in the self-replicating plasmid pSRF4, these polypeptides are dispensable for autonomous replication of pCG 100 . The $32 \mathrm{kDa}$ protein, in contrast, is absolutely required for self-replication since insertion at the SphI site abolished autonomous replication. It is tempting to assume that the $32 \mathrm{kDa}$ protein is the replication protein. Its molecular mass is in agreement with that of other Gram-positive replication proteins, which vary from 25 to $40 \mathrm{kDa}$ (del Solar et al., 1987; Khan et al., 1988; Byeon \& Weisblum, 1990).

Deletions starting at EcoRI and extending to the $N c o l$ and $B c /$ I sites (pSRB $1 \Delta \mathrm{E}, \mathrm{pSRB} 3 \triangle \mathrm{B} / \mathrm{Bg}$ ) affected selfreplication, but not the production of the $32 \mathrm{kDa}$ protein in the pT7 system. pSRF4, containing the $1.9 \mathrm{~kb} \mathrm{Bg} / \mathrm{II}-$ NcoI fragment, is able to replicate autonomously. Since no origin of replication was detected in this region, it is likely that the EcoRI site is located within the promoter region or between the promoter and the coding sequence for the presumptive replication protein.

Some derivatives of pCG100 could replicate only when trans-complemented by pCG100. They all contained the $0 \cdot 4 \mathrm{~kb} S p h \mathrm{I}-$ HindIII $_{\mathrm{b}}$ fragment which should contain the replication origin of pCG100. It is located within or close to the $3^{\prime}$ end of the $32 \mathrm{kDa}$ presumptive replication protein gene.

The HindIII $\mathrm{b}_{\mathrm{b}}-$ BgIII segment downstream of the sequence coding for the $32 \mathrm{kDa}$ protein and the cis-acting replication origin sequence is required for autonomous replication. This segment, of less than $200 \mathrm{bp}$, is too short to encode the $14.2 \mathrm{kDa}$ polypeptide located in this region, making it unlikely that this polypeptide is involved in pCG100 replication. No other polypeptide was detected in this region, so it is tempting to speculate that an RNA encoded in this region may be necessary for pCG100 replication.

Derivatives of pCG100 containing the minimal autonomous replication region are incompatible with pCG100. This incompatibility results either from a control of plasmid copy number, as observed for many replicons (Scott, 1984), or from competition for the replication protein (Novick, 1989). Since pCG100 is compatible with $\mathrm{pBLl}$, the replication mechanisms of these two plasmids do not interact, proving that they are two distinct replicons.

The data presented in this report locate the replication origin of pCG100 and identify the sequence for a $32 \mathrm{kDa}$ putative replication protein. The characterization of the minimal replication region allowed the construction of new shuttle vectors for cloning in most corynebacteria since pCG100 seems to have a wide host spectrum. The precise identification of the replication mechanisms will require the purification of the various components, including the replication protein, in order to develop an in vitro assay as described for pT181 (Gennaro et al.,
1989) and pMU158 (del Solar et al., 1987). This should be possible, since the presumptive replication protein is highly expressed in the pT7 expression system.

Three new E. coli-Corynebacterium shuttle vectors were constructed. They contain either the P15A or the ColE1 replication origin for $E$. coli and the $1.9 \mathrm{~kb}$ minimal region necessary for autonomous replication in corynebacteria. They present original features in comparison with those already described (Martin, 1989), namely numerous cloning sites enabling resistance gene or lac $Z \alpha$ inactivation detectable in $E$. coli. In corynebacteria, the $E$. coli lac genes are expressed from their own promoter, this expression being controlled by the lacI gene product (Tsuchiya \& Morinanga, 1988). Thus a $\beta$-galactosidase $\alpha$ complementation system for insert detection in corynebacteria may be feasible after introduction of $\operatorname{lac} Z \beta$ on a $\mathrm{pBLl}$ derivative which is compatible with pCG100. Such a strategy was successfully used in Bacillus subtilis (Haima et al., 1990).

\section{References}

Archer, J. A. C., Follettie, M. T. \& Sinskey, A. J. (1989). Biology of Corynebacterium glutamicum: a molecular approach. In Genetics and Molecular Biology of Industrial Microorganisms, pp. 27-33. Edited by C. L. Hershberger, S. W. Queener \& G. Hegeman. Washington, DC: American Society for Microbiology.

BiRnBoim, H. C. \& Doly, J. (1979). A rapid alkaline extraction procedure for screening recombinant plasmid DNA. Nucleic Acids Research 7, 1513-1524.

Bonnassie, S., Burini, J. F., Oreglia, J., Trautwetter, A., Patte, J. C. \& SiCARD, M. (1990). Transfer of plasmid DNA to Brevibacterium lactofermentum by electroporation. Journal of General Microbiology 136, 2107-2112.

Bousfield, I. J. \& Callely, A. G. (editors) (1978). Coryneform Bacteria. London: Academic Press.

ByeON, W. H. \& WeisBlum, B. (1990). Replication genes of plasmid $\mathrm{pE} 194$ cop and repF: transcripts and encoded proteins. Journal of Bacteriology 172, 5892-5900.

ChATER, K. F., HopwoOd, D. A., Kieser, T. \& Thompson, C. J. (1982). Gene cloning in Streptomyces. Current Topics in Microbiology and Immunology 97, 69-95.

CrombaCH, W. H. J. (1978). DNA base ratios and DNA hybridization studies of coryneform bacteria, mycobacteria and nocardiae. In Coryneform Bacteria, pp. 161-179. Edited by I. J. Bousfield \& A. G. Callely. London: Academic Press.

Fellay, R., FreY, J. \& KRISCH, H. (1987). Interposon mutagenesis of soil water bacteria : a family of DNA fragments designed for in vitro insertional mutagenesis of Gram-negative bacteria. Gene 52, 147 154.

Filpula, D., Ally, A. H. \& Nagle, J. (1986). Complete nucleotide sequence of a native plasmid of Brevibacterium lactofermentum. Nucleic Acids Research 14, 5114.

Gennaro, M. L., Iordanescu, S., Novick, R. P., Murray, R. W., STECK, T. R. \& KHAN, S. A. (1989). Functional organization of the plasmid pT181 replication origin. Journal of Molecular Biology 205, 355-362.

Haima, P., Sinderen, D. V., Bron, S. \& Venema, G. (1990). An improved $\beta$-galactosidase $\alpha$-complementation system for molecular cloning in Bacillus subtilis. Gene 93, 41-47.

Heusterpreute, M., Thi, V. H., Emery, S., Tournis-Gamble, S., KenNEDY, N. \& Davison, J. (1985). Vectors with restriction site banks. IV. pJRD184, a 3793-bp plasmid cloning vector having 43 unique cloning sites. Gene 39, 299-304. 
Khan, S. A., Murray, R. W. \& Koepsel, R. R. (1988). Mechanism of plasmid pT181 DNA replication. Biochimica et Biophysica Acta 951, 375-381.

LAEMmLI, U. K. (1970). Cleavage of structural proteins during the assembly of the head of bacteriophage T4. Nature, London 227, 680 685.

Mandel, M. \& HigA, A. (1970). Calcium-dependent bacteriophage DNA infection. Journal of Molecular Biology 53, 159-162.

Maniatis, T., Fritsch, E. F. \& SambrooK, J. (1962). Molecular Cloning. A Laboratory Manual. Cold Spring Harbor, NY: Cold Spring Harbor Laboratory.

MARTIN, J. F. (1989). Molecular genetics of amino acid-producing corynebacteria. Symposia of the Society for General Microbiology 44, 25-59.

MaRTINEZ, E., BarTolomÉ, B. \& DE LA CRUZ, F. (1988). pACYC184derived cloning vectors containing the multiple cloning site and lacZ $\alpha$ reporter gene of $\mathrm{pUC} 8 / 9$ and $\mathrm{pUC} 18 / 19$ plasmids. Gene 68 , $159-162$.

Mead, D. A., Skorupa, E. S. \& Kemper, B. (1985). Single stranded DNA SP6 promoter plasmid for engineering mutant RNAs and proteins, synthesis of a 'stretched' preproparathyroid hormone. Nucleic Acids Research 13, 1103-1118.

Miller, J. (1972). Experiments in Molecular Genetics. Cold Spring Harbor, NY: Cold Spring Harbor Laboratory.

MiWa, K., Matsui, K., Terabe, M., Ito, K., Ishida, M., Takagi, H., NAKAMORI, S. \& Sano, K. (1985). Construction of novel shuttlevectors and a cosmid vector for the glutamic acid-producing bacteria Brevibacterium lactofermentum and Corynebacterium glutamicum. Gene 39, 281-286.

Novick, R. P. (1989). Staphylococcal plasmids and their replication. Annual Review of Microbiology 43, 537-565.

Ozaki, A., Katsumata, R., OKa, T. \& Furuya, A. (1984). Functional expression of the genes of Escherichia coli in gram-positive Corynebacterium glutamicum. Molecular and General Genetics 196, 175-178.
Russel, M. \& Model, P. (1984). Replacement of the fip gene of Escherichia coli by an inactive gene cloned on a plasmid. Journal of Bacteriology 159, 1034-1039.

Santamaria, R. I., Gil, J. A., Mesas, J. M. \& Martin, J. F. (1984). Characterization of an endogenous plasmid and development of cloning vectors and a transformation system in Brevibacterium lactofermentum. Journal of General Microbiology 130, 2237-2246.

Santamaria, R. I., Gil, J. A. \& Martin, J. F. (1985). High-frequency transformation of Brevibacterium lactofermentum protoplasts by plasmid DNA. Journal of Bacteriology 162, 463-467.

ScotT, J. R. (1984). Regulation of plasmid replication. Microbiological Reviews 48, 1-23.

Del Solar, G., Diaz, R. \& Espinosa, L. (1987). Replication of the streptococcal plasmid pMV158 and derivatives in cell-free extracts of Escherichia coli. Molecular and General Genetics 206, 428-435.

Spratt, B. G., Hedge, P. J., Te Heesen, S., Edelman, A. \& BroomeSMITH, J. K. (1986). Kanamycin-resistant vectors that are analogues of plasmids pUC8, pUC9, pEMBL8 and pEMBL9. Gene 41, 337342.

TABOR, S. \& Richardson, C. C. (1985). A bacteriophage T7 RNA polymerase/promoter system for controlled exclusive expression of specific genes. Proceedings of the National Academy of Sciences of the United States of America 82, 1074-1078.

Trieu-Cuot, P. \& Courvalin, P. (1983). Nucleotide sequence of the Streptococcus faecalis plasmid gene encoding the $3^{\prime}, 5^{\prime}$-aminoglycoside phosphotransferase type III. Gene 23, 331-341.

TsuChIYA, M. \& MoRinaGa, Y. (1988). Genetic control systems of Escherichia coli can confer inducible expression of cloned genes in coryneform bacteria. Bio/Technology 6, 428-430.

Yeh, P., Oreglia, J., Prévots, F. \& Sicard, A. M. (1986). A shuttle vector system for Brevibacterium lactofermentum. Gene 47, 301-306.

Yoshihama, M., Higashiro, K., Rao, E. A., Akedo, M., Shanabruch, W. G., Follettie, M. T., WAlKer, G. C. \& SinSKey, A. J. (1985). Cloning vector system for Corynebacterium glutamicum. Journal of Bacteriology 162, 591-597. 